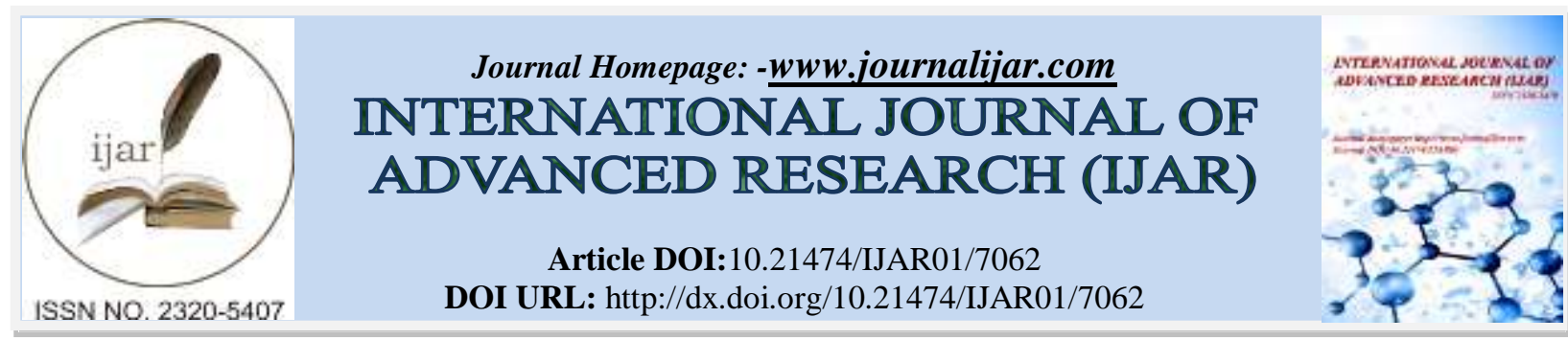

RESEARCH ARTICLE

\title{
ANTIBACTERIAL AND BIOPRESERVATIVE EFFECT OF BACTERIOCIN PRODUCED BY ENTEROCOCCUS FAECIUM.
}

Bandi Aruna ${ }^{1}$ and Vanamala Sruthi ${ }^{1}$. Department of Microbiology, St. Francis College for Women, Begumpet, Hyderabad, Telangana State 500016 India.

\section{Manuscript Info}

Manuscript History

Received: 08 March 2018

Final Accepted: 10 April 2018

Published: May 2018

Keywords:-

Bacteriocin, Lactic acid bacteria,

Enterococcus, Antagonistic activity, Biopreservative agent.

\begin{abstract}
Bacteriocin producing lactic acid bacteria (LAB) from fermented foods are of great significance because of their potential use as antibacterial activity against similar or closely related bacterial strains. The present study was focused on detection of antibacterial activity of bacteriocin producing $\mathrm{LAB}$ from fermented green gram batter. The three isolates (A3R, A5R and A8R) were identified as Enterococcus faecium by $16 \mathrm{~S}$ ribosomal DNA (rDNA). The bacteriocin of three isolates was evaluated for antagonistic activity against indicator organisms, Pseudomonas aeruginosa, Staph aureus and Escherichia coli. The bacteriocin of A3R and A5R inhibited the growth of P. aeruginosa and $S$.aureus. The growth of $E$. coli was inhibited by bacteriocin of A5R and A8R, not inhibited by bacteriocin of A3R. The study revealed high bacteriocin production by A5R. The sensitivity of the extracted bacteriocin to proteolytic enzymes, indicated the proteinaceous nature of bacteriocin. The preservative effect of ascorbic acid was enhanced in presence of bacteriocin of A3R, indicating its suitability as biopreservative agent in coconut water. The isolation and identification of Enterococcus faecium is one of the lactic acid bacteria involved in green gram fermentation and production of bacteriocin.
\end{abstract}

Copy Right, IJAR, 2018,. All rights reserved.

\section{Introduction:-}

Lactic acid bacteria (LAB) is an important group of industrial microorganism involved in the processing of various fermented food which include vegetables and sausages, dietary adjuncts, probiotics and even cosmetic ingredients. $\mathrm{LAB}$ is used as starter culture to improve the texture and the flavour of the products. The ability to inhibit growth of spoilage microorganisms and pathogenic bacteria contribute to the maintenance of hygienic and quality of the products or host health. This inhibitory activity is the result of the metabolic product secreted by these LAB which acts as antimicrobial compounds. These compounds include organic acids, diacetyl, hydrogen peroxide and bacteriocin (Barefoot and Klaenhammer, 1983).

Bacteriocins, are defined as bioactive peptides or protein, extracellularly released, with an antimicrobial activity towards gram positive bacteria including closely related species and/or food spoilage and pathogenic bacteria such as Bacillus cereus, Clostridium botulinum, Staphylococcus aureus and Listeria monocytogenes (Nettles and Barefoot, 1993). Although the bacteriocins are produced by many Gram-positive and Gram-negative bacteria, those produced by LAB are of particular interest because known as "good bacteria" used as natural preservatives in food 
industry (Paul et al., 2002). During the last few years a large number of new LAB bacteriocins have been identified and characterized. However only few have been described to possess activities against Gram-negative bacteria, e.g. plantaricin 35d produced by Lactobacillus plantarum (Meesi et al., 2001), Bacteriocin ST34BR produced by L.lactis subsp. Lactis (Todorov et al., 2004c).

The use of bacteriocin or bacteriocin producing culture as potential 'biopreservatives', and possibly for replacing chemical preservatives (Abee et al., 1995) has received much attention. This is due to current awareness of consumers towards the use of food preservatives. Therefore the purpose of this study was aimed at isolation of lactic acid bacteria from green gram (Vigna radiata) fermented batter, for their ability to produce bacteriocin which exhibit antagonistic activity and biopreservative property.

\section{Material and Methods:-}

\section{Sample collection and preparation:-}

Green gram was collected, cleaned, soaked in water for $8 \mathrm{hr}$ and batter was prepared. It was allowed to ferment at room temperature overnight $(\mathrm{O} / \mathrm{N})$.

Isolation and identification of bacteriocin producing Lactic acid bacteria (LAB):-

The fermented batter of $1 \mathrm{ml}$ was added to $9 \mathrm{ml}$ of distilled water, serial dilutions were performed up to $10^{-7}$ and plated on Man, Rogosa and Sharpe (MRS) agar. The plates were incubated at $37^{\circ} \mathrm{C}$ for $24 \mathrm{hr}$. After incubation, pure culture was made on MRS agar and tested for bacteriocin production (Nettles and Barefoot, 1993). Then the isolates were Gram stained and examined microscopically. Based on Bergey's Manual of Systemic Bacteriology (Ravi et al., 2011), isolates were tested for their ability to ferment dextrose, lactose, sucrose and mannitol. Catalase activity was tested by spotting colonies with $3 \%$ hydrogen peroxide and Oxidase by using oxidase disc.

\section{Carbohydrate fermentation test:-}

The carbohydrate fermentation of the LAB isolates using the dextrose (1\%), lactose (1\%) sucrose (1\%) and mannitol (1\%) was identified by using basal medium (peptone water). The inverted Durham's tubes were placed in the medium to detect the formation of gas. Incubation was carried out at $37^{\circ} \mathrm{C}$ for $18-48 \mathrm{hr}$ and results were recorded at 18-24 hr. The methylene blue was used as an indicator, positive result (acid production) was indicated by yellow colour and negative result (no acid production) was indicated by blue colour (Kozaki et al., 1992).

\section{Antibiotic susceptibility test:-}

Antimicrobial susceptibility testing of isolates were performed using commercially available predefined gradient of antibiotic concentrations on a plastic strip (Hi-Media) by using nutrient agar.

\section{Production and concentration of bacteriocin in culture supernatant:-}

Isolates were grown in MRS broth at $37^{\circ} \mathrm{C}$ for $48 \mathrm{hr}$ under rotatory (incubate shaker) condition. After incubation, the broth was centrifuged at $5000 \mathrm{rpm}$ for $10 \mathrm{~min}$ and the cells were separated (Esayas et al., 2008). The cell free supernatant was used as crude bacteriocin. The bacteriocin reacted with Folin Ciocalteau reagent, Lowry method (Lowry et al., 1951) and formed a complex which is blue purple color complex which was read at $660 \mathrm{~nm}$ in spectrophotometer. Bovine serum albumin (BSA) was used as a standard protein.

\section{Antibacterial activity of bacteriocin against indicator organisms:-}

The antibacterial activity of bacteriocin of all three isolates was tested against indicator organisms, Gram positive organism (Staphylococcus aureus) and Gram negative organisms (Escherichia coli, Pseudomonas aeruginosa,). The $\mathrm{pH}$ of culture supernatants was adjusted to $\mathrm{pH} 5$ and $\mathrm{pH} 7$ using $1 \mathrm{M} \mathrm{NaOH}$. The antimicrobial activity of bacteriocin against pathogenic microorganisms was determined by agar well diffusion method (Gomez et al., 2002). Nutrient agar plates were inoculated with $100 \mathrm{ul}$ (Nutrient broth containing $\mathrm{O} / \mathrm{N}$ culture) of each indicator microorganism by spread plate method and inhibitory activity of bacteriocins against indicator organisms was tested by agar well diffusion method.

Antibacterial activity of bacteriocin in presence of proteinase $\mathrm{K}$ :-

The proteinase $\mathrm{K}(1 \mathrm{mg} / \mathrm{ml})$ was added to culture supernatant (bacteriocin), incubated at $37^{\circ} \mathrm{C}$ for $1 \mathrm{hr}$ and evaluated for antibacterial activity of bacteriocin of three isolates by agar well diffusion (Diaz et al., 1993). 
Preservative property of ascorbic acid in presence of A3R bacteriocin in coconut water:-

Coconut was obtained aseptically in the laboratory. The preservative effect of ascorbic acid as chemical preservative (CP) in presence of bacteriocin as biopreservative (BP) was investigated. The set of seven boiling tubes were used for the experiment. To all seven tubes $5 \mathrm{ml}$ of coconut water was added. First tube was the control (no preservative was added). To the second tube BP (1\%), third CP (1\%), fourth BP (4\%), fifth CP (4\%) were added. The sixth and seventh tubes contained combination of both BP and CP. To the sixth tube (BP $1 \%+$ CP 1\%) and seventh tube (BP 4\% + CP 4\%) were added. All the seven tubes were incubated at room temperature for $24 \mathrm{hr}, 100$ ul of sample from each flask was inoculated on nutrient agar medium by spread plate method, incubated at $37^{\circ} \mathrm{C}$ for $24 \mathrm{hr}$ and observed for microbial colonies.

\section{Sequence of Isolates A3R, A5R and A8R:-}

The sequencing of three isolates A5R and A3R were analysed using the method, 16S rDNA, done by Zeal Biologicals, Secunderabad, Telangana State.

\section{Results:-}

Isolation and identification of bacteriocin producing Lactic acid bacteria (LAB):-

The three isolates A3R, A5R and A8R, bacteriocin producing Lactic acid bacteria were isolated from fermented green gram batter, identified as Enterococcus faecium based on their physiological, biochemical (Table 1) and molecular characteristics by $16 \mathrm{~S}$ rDNA. The isolates A3R, A5R and A8R were Gram-positive cocci, catalase negative, acid production in dextrose and lactose fermentation and no hemolysis, having small, smooth round colonies on MRS agar medium.

Table 1:-General Properties of Isolates

\begin{tabular}{|c|c|c|c|}
\hline SAMPLE & ISOLATE & GENERAL PROPERTIES & $\begin{array}{c}\text { IDENTIFIED } \\
\text { ORGANISM }\end{array}$ \\
\hline Green gram & A3R & $\begin{array}{c}\text { Gram positive cocci, Catalase -ve, Oxidase-ve, } \\
\text { Coagulase-ve, no hemolysis, acid production in } \\
\text { dextrose and lactose }\end{array}$ & Enterococcus faecium \\
\hline Green gram & A5R & $\begin{array}{c}\text { Gram positive cocci, Catalase -ve, Oxidase-ve, } \\
\text { Coagulase-ve, no hemolysis, acid production in } \\
\text { dextrose and lactose }\end{array}$ & Enterococcus faecium \\
\hline Green gram & A8R & $\begin{array}{c}\text { Gram positive cocci, Catalase -ve, Oxidase-ve, } \\
\text { Coagulase-ve, no hemolysis, acid production in } \\
\text { dextrose and lactose }\end{array}$ & Enterococcus faecium \\
\hline
\end{tabular}

-ve: Negative

\section{Carbohydrate fermentation test:-}

The carbohydrate fermentation pattern (Table 2) of three isolates (A3R, A5R and A8R) using the dextrose (1\%), lactose $(1 \%)$ sucrose $(1 \%)$ and mannitol $(1 \%)$ in peptone water.

Table 2:- Carbohydrates fermentation of isolates

\begin{tabular}{|c|c|c|c|c|c|c|c|c|}
\hline ISOLATE & \multicolumn{2}{|c|}{ DEXTROSE } & \multicolumn{2}{c|}{ LACTOSE } & \multicolumn{2}{c|}{ SUCROSE } & \multicolumn{2}{c|}{ MANNITOL } \\
\hline & AP & GP & AP & GP & AP & GP & AP & GP \\
\hline A3R & + & - & - & - & + & - & - & - \\
\hline A5R & + & - & - & - & + & - & - & - \\
\hline A8R & + & - & - & - & + & - & - & - \\
\hline
\end{tabular}

AP: Acid production, GP: Gas production,

AP +: Presence of Acid production, AP -: No Acid production, GP -: No gas production

Antibiotic susceptibility test:-

The antibiotic susceptibility testing of isolates indicated in Table 3. The three isolates were resistant to all twelve antibiotics. 
Table 3:- Antibiotic susceptibility testing of isolates

\begin{tabular}{|l|c|c|c|}
\hline \multicolumn{1}{|c|}{ ANTIBIOTIC } & A3R & A5R & A8R \\
\hline Amikacin & $\mathrm{r}$ & $\mathrm{r}$ & $\mathrm{r}$ \\
\hline Ampiclox & $\mathrm{r}$ & $\mathrm{r}$ & $\mathrm{r}$ \\
\hline Ciprofloxacin & $\mathrm{r}$ & $\mathrm{r}$ & $\mathrm{r}$ \\
\hline Clarithromycin & $\mathrm{r}$ & $\mathrm{r}$ & $\mathrm{r}$ \\
\hline Cefotaxime & $\mathrm{r}$ & $\mathrm{r}$ & $\mathrm{r}$ \\
\hline Sparfloxacin & $\mathrm{r}$ & $\mathrm{r}$ & $\mathrm{r}$ \\
\hline Cefuroxime & $\mathrm{r}$ & $\mathrm{r}$ & $\mathrm{r}$ \\
\hline Cefoperazone & $\mathrm{r}$ & $\mathrm{r}$ & $\mathrm{r}$ \\
\hline Gentamicin & $\mathrm{r}$ & $\mathrm{r}$ & $\mathrm{r}$ \\
\hline Roxithromycin & $\mathrm{r}$ & $\mathrm{r}$ & \\
\hline Cefadroxil & $\mathrm{r}$ & & $\mathrm{r}$ \\
\hline Azithromycin & $\mathrm{r}$ & \\
\hline
\end{tabular}

r: Resistant

Production and concentration of bacteriocin in culture supernatant:-

The bacteriocin production (Table 4 and Figure 1) was estimated in culture supernatant of isolates A3R, A5R and $\mathrm{A} 8 \mathrm{R}$ at $37^{\circ} \mathrm{C}$ under rotatory condition (Incubate shaker). The concentration of bacteriocin was $0.17 \mathrm{mg} / \mathrm{ml}(\mathrm{A} 3 \mathrm{R})$, $0.21 \mathrm{mg} / \mathrm{ml}$ (A5R) and $0.14 \mathrm{mg} / \mathrm{ml}$ (A8R). The highest production of bacteriocin was observed with A5R.

Table 4:-Concentration of bacteriocin in culture supernatants of A3R, A5R and A8R

\begin{tabular}{|c|c|}
\hline ISOLATE & CONCENTRATION OF PROTEIN mg/ml \\
\hline A3R & 0.17 \\
\hline A5R & 0.21 \\
\hline A8R & 0.14 \\
\hline
\end{tabular}

Figure 1:-Concentration of crude bacteriocin $(\mathrm{mg} / \mathrm{ml})$

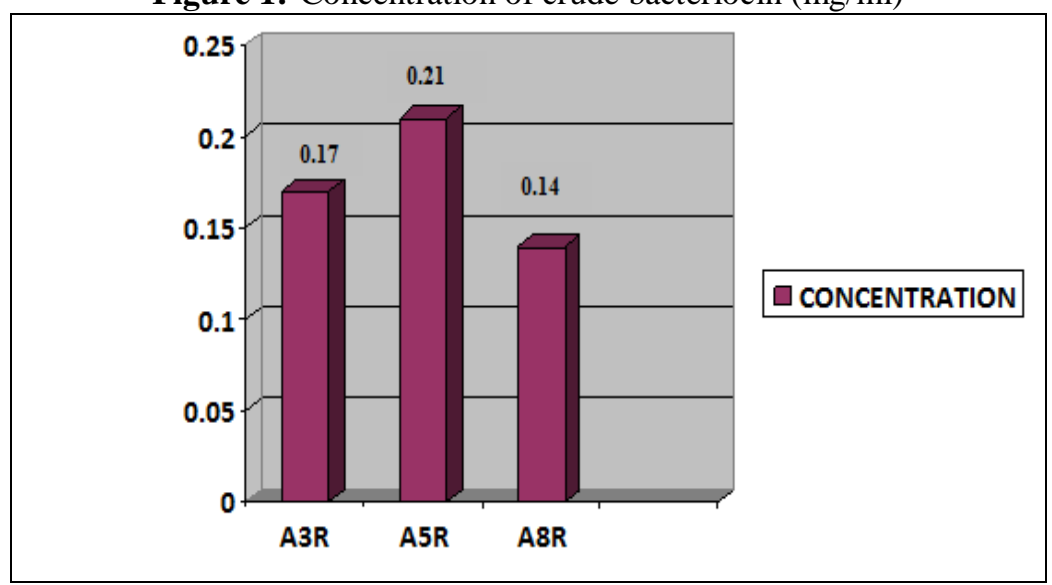

A3R:- Bacteriocin production at $37^{\circ} \mathrm{C}$ under rotatory condition (Incubate shaker)

A5R:- Bacteriocin production at $37^{\circ} \mathrm{C}$ under rotatory condition (Incubate shaker).

A8R:- Bacteriocin production at $37^{\circ} \mathrm{C}$ under rotatory condition (Incubate shaker).

Antibacterial activity of bacteriocin against indicator organisms:-

Tables 5, 6, 7, 8 indicate the antibacterial activity of three isolates at $\mathrm{pH} 5$ and $\mathrm{pH}$ 7. The bacteriocin of A5R and A8R inhibited the growth of E. coli and P. aeruginosa and $S$. aureus at pH5. The bacteriocin of A35R inhibited the growth of $P$. aeruginosa and $S$. aureus at $\mathrm{pH} 5$. The indicator organisms were resistant to bacteriocin of three isolates at $\mathrm{pH} 7$. 
Table 5:-Antibacterial activity of bacteriocin

\begin{tabular}{|c|c|c|c|c|c|c|}
\hline ISOLATES & \multicolumn{3}{|c|}{ ZONE OF INHIBITION (mm) } \\
\hline & \multicolumn{2}{|c|}{ E.coli } & \multicolumn{2}{c|}{ P.aeruginosa } & \multicolumn{2}{c|}{ S.aureus } \\
\hline & $\mathrm{pH}$ & $\mathrm{pH}$ & $\mathrm{pH}$ & $\mathrm{pH}$ & $\mathrm{pH5}$ & $\mathrm{pH7}$ \\
\hline A3R & - & - & 16 & - & 14 & - \\
\hline A5R & 12 & - & 18 & - & 17 & - \\
\hline A8R & 12 & - & 15 & - & 16 & - \\
\hline
\end{tabular}

(-): No zone of inhibition

Table 6:-Antibacterial activity of bacteriocin of three isolates with E.coli

\begin{tabular}{|c|c|}
\hline ISOLATES & /ONE OF INHIBITION (mm) \\
PH S
\end{tabular}

r: resistant (No zone of inhibition) s: sensitive (Presence of zone of inhibition)

Table 7:-Antibacterial activity of bacteriocin of three isolates with P.aeruginosa

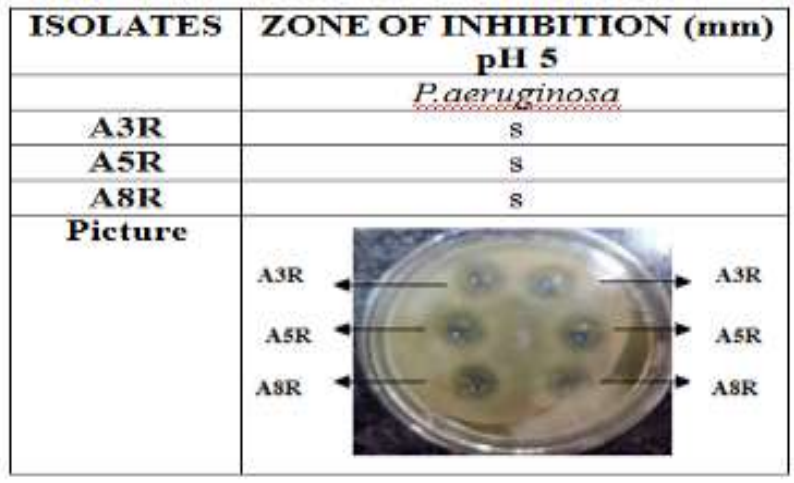

s: sensitive (Presence of zone of inhibition)

Table 8:-Antibacterial activity of bacteriocin of three isolates with S.aureus

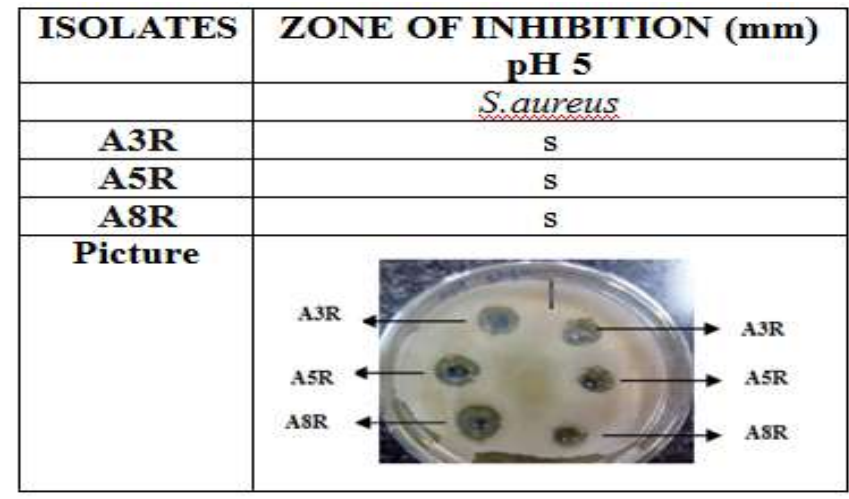

s: sensitive (Presence of zone of inhibition) 


\section{Antibacterial activity of bacteriocin in presence of proteinase K:-}

The sensitivity of bacteriocin of isolates (A3R, A5R and A8R) to proteinase K was evaluated (Table 9), indicator organisms were resistant to bacteriocin, indicating loss of antibacterial activity.

Table 9:-Antibacterial activity of bacteriocin in presence of Proteinase K

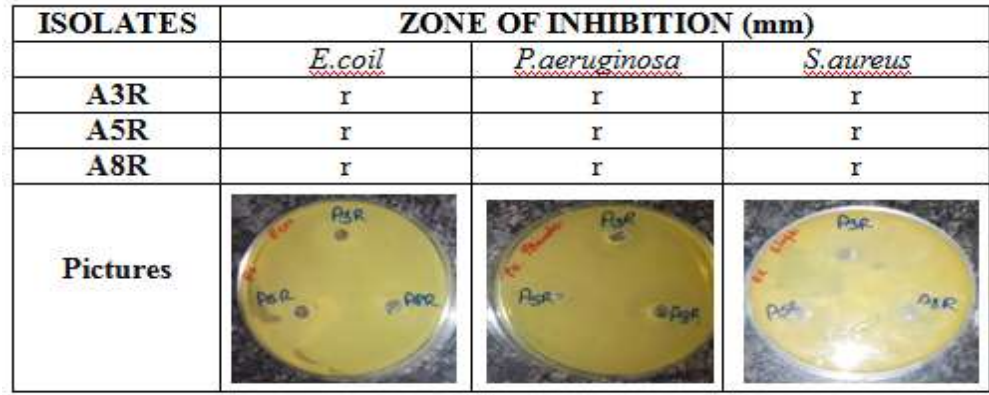

r: resistant (No zone of inhibition)

Effect of preservative property of ascorbic acid in presence of A3R bacteriocin in coconut water:-

The bacteriocin of A3R as biopreservative (BP) agent in coconut water (Table 10) was investigated based on the number of colonies. The number of colonies reduced in the presence of bacteriocin (1\% \& 4\%) and ascorbic acid $(1 \% \& 4 \%)$ as chemical preservative (CP). The maximum reduction in the number of colonies was observed in the combination of $\mathrm{BP}+\mathrm{CP}(1 \%+1 \%)$. The preservative effect was further enhanced in the combination of increased concentration of $\mathrm{BP}+\mathrm{CP}(4 \%+4 \%)$, indicated by presence of few colonies.

Table 10:- Preservative property of ascorbic acid in presence of A3R bacteriocin in coconut water

\begin{tabular}{|l|l|l|}
\hline $\begin{array}{l}\text { COCONUT WATER } \\
+ \text { PRESERVATIVE }\end{array}$ & $\begin{array}{l}\text { MICROFLORA } \\
\text { (COLONIES) }\end{array}$ & PICTURES \\
\hline $\begin{array}{l}\text { Only coconut water } \\
\text { Control) }\end{array}$ & Lawn of growth \\
\hline $\begin{array}{l}\text { Coconut water + BP } \\
(1 \%)\end{array}$ & $\begin{array}{l}\text { Decrease in the } \\
\text { number of colonies }\end{array}$ & \\
\hline $\begin{array}{l}\text { Coconut water }+\mathrm{CP} \\
(1 \%)\end{array}$ & $\begin{array}{l}\text { Decrease in the } \\
\text { number of colonies }\end{array}$ & $\begin{array}{l}\text { Maximum reduction in } \\
\text { the number of colonies }\end{array}$ \\
\hline $\begin{array}{l}\text { Coconut water }+\mathrm{BP} \\
(4 \%)\end{array}$ & $\begin{array}{l}\text { Maximum reduction in } \\
\text { the number of colonies }\end{array}$ \\
\hline $\begin{array}{l}\text { Coconut water }+\mathrm{CP} \\
(4 \%)\end{array}$ & $\begin{array}{l}\text { Decrease in the } \\
\text { number of colonies }\end{array}$ \\
\hline $\begin{array}{l}\text { Coconut water }+ \\
\mathrm{B} \text { P }(1 \%)+\mathrm{CP}(1 \%)\end{array}$ & $\begin{array}{l}\text { Very few colonies } \\
\text { were observed } \\
\text { BP }(4 \%)+\mathrm{CP}(4 \%)\end{array}$ \\
\hline
\end{tabular}

BP:-Bacteriocin as Biopreservative (Concentration:1\% \& 4\%)

CP:-Ascorbic acid as Chemical preservative (Concentration:1\% \& 4\%) 


\section{Sequencing results of Isolates A3R, A5R and A8R:-}

The sequencing of two isolates A5R and A3R were analysed by $16 \mathrm{~S}$ rDNA and identified as:

1. A3R - Enterococcus faecium (NRIC 0114; AB362603.E).

2. A5R - Enterococcus faecium (NRIC 0114; AB362603.E).

3. A8R - Enterococcus faecium (NRIC 0114; AB362603.E).

\section{Discussion:-}

The LAB is considered as "food grade" organisms, show special promise for selection and implementation as protective cultures. In addition, some LAB exhibit potent antimicrobial activities in the form of small, heat-stable, antimicrobial peptides called bacteriocins (Riley and Wertz, 2002). The bacteriocins are proteinaceous compounds that are able to inhibit to a wide variety of organisms, mostly closely related to the producer organisms (Mandal et al., 2011).

The three isolates showed the activity of acidification with dextrose and sucrose and produced no gas. The two isolates didn't ferment lactose and mannitol. Lact. plantarum 20B produced lactic acid when maltose was used, and markedly increased growth rate and the production of acetic acid (Kandler, 1983).

The results indicate that the transfer of resistance gene between isolates might have occurred, that lead to the development of resistance to all the twelve antibiotics by isolates. The antibiotic resistance genes can spread from one bacterium to another through several mechanisms. Intrinsic resistance is estimated to present a minimal potential for horizontal spread (between different bacterial species), demonstrated for example with the chromosomal vancomycin resistance determinant of the Lactobacillus rhamnosus strain GG (Tynkkynen et al., 1998).

The effect of $\mathrm{pH}$ played an important role in the antibacterial activity of bacteriocins. The bacteriocin of A3R, A5R and A8R inhibited the growth of common food spoilage bacteria at $\mathrm{pH}$ 5. The bacteriocins of these isolates may be useful as biopreservative agents in food industry. $\mathrm{LAB}$ are more tolerant to acidic $\mathrm{pH}$ and other organisms are inhibited at low pH and most of the LAB thrive best at a pH < 4.5 (Aroutcheva et al., 2001; Linhares et al., 2011; Redondo-Lopez et al., 1990).

The absence of antibacterial activity (absence of zone of inhibition) indicate the degradation of bacteriocins in presence of Proteinase K, suggested the proteinaceous nature of bacteriocin. The similar studies, sensitivity of the extracted bacteriocin to proteolytic enzymes, indicated the proteinaceous nature of bacteriocin (Deraz et al., 2005).

The bacteriocin production varies with the different isolates. Variation in the concentration of was due to the amount of bacteriocin produced by isolates. Studies in our laboratory revealed the fermented green gram batter was a potential source of lactic acid bacteria, produced bacteriocins. Similar studies were performed and tested for bacteriocin production by Lactobacillus isolates (Mohankumar and Murugalantha, 2011).

The preservative effect of $\mathrm{CP}$ was enhanced in the presence of bacteriocin (BP) at two different concentrations (1\% $\& 4 \%)$ in coconut water, increased the preservative effect of $\mathrm{CP}$, indicated bacteriocin as potent biocontrol agent against food spoilage microorganisms. The bacteriocin of A3R isolate could serve as potential biopreservative agent in food industry. Vescovo et al (1995) observed a reduction in high initial bacterial loads of ready-to-use mixed salads on addition of bacteriocin producing LAB. The bacteriocin producing starter cultures are useful for fermentation of sauerkraut or olives to prevent the growth of spoilage organisms (Schillinger et al 1996). This study would help the use of synergistic effects of these natural preservatives in combination with advanced hurdle technologies could result in replacement of chemical preservatives and could allow in maintaining the quality of food.

\section{Acknowledgements:-}

The authors acknowledge and thank Management of St. Francis College for Women, Begumpet, Hyderabad for their support and encouragement. 


\section{References:-}

1. Abee, T., Krockel L., Hill C. (1995). Bacteriocin: mode of action and potential food preservation and control of food poisoning. Int. J. Food Microbiol. 28: 169-85.

2. Aroutcheva, A., Gariti, D., Simon, M., Shott, S., Faro, J., Simoes, A., Gurguis, A. and Faro, S. (2001). Defense factors of vaginal lactobacilli. Am J Obstet Gynecol. 185: 375-379.

3. Barefoot, S.F., Klaenhammer, T.R. (1983). Detection and activity of Lactacin B, a bacteriocin produced by Lactobacillus acidophilus. Appl. Environ. Microbiol. 45: 1808-15.

4. Deraz, S., Karlsson, N.E., Hedstrom, M., Andersson, M.M., Mattiasson, B. (2005). Purification and characterization of acidocin D20079 a bacteriocin produced by Lactobacillus acidophilus DSM 20079. J Biotech. 117: 343-354.

5. Diaz, R., Sanchez, R.M.R., Desmazeud, M., Ruiz-Barba, J.L. and Piard, J.C. (1993). Plantaricin S and T, two new bacteriocins prduced by Lactobacillus plantarum LPC010 isolated from a green olive fermentation. Appl. Environ. Microbiol. 59: 1416-1424.

6. Esayas A, Fekadu B and Amutham S. 2008. Isolation and characterizing of inhibitory substance producing lactic acid bacteria from Ergo, Ethiopian traditional fermented milk. Afri J Microbiol Res 2: 229-234.

7. Gomez, R., Munoz, M., de Ancos, B. and Cano, M.P. (2002). New Procedure for the Detection of Lactic acid Bacteria in Vegetables Producing Antibacterial Substances. Lebensmittel-Wissenschaft und-Technologie. 35: 284-288.

8. Kandler, O. (1983). Carbohydrate metabolism in lactic acid bacteria. Antonie van Leeuwenhoek. J Microbiol. 49: 209-224.

9. Kozaki, M., Uchimura, T. and Okada, S. (1992). Experimental Manual for Lactic Acid Bacteria, Tokyo: Asakurasyouten. 29-72.

10. Linhares, I.M., Summers, P.R., Larsen, B., Giraldo, P.C. and Witkin, S.S. (2011). Contemporary perspectives on vaginal $\mathrm{pH}$ and lactobacilli. Am J Obstet Gynecol. 204: 120.e1-5.

11. Lowry, O.H., Rosebrought, N.J., Farr, A.L. and Randall, R. J. (1951). Protein measurement with the Folin phenol reagent. J. Biol. Chem. 193(1): 265-75.

12. Mandal, V., Sen, S.K., Mandal, N.C. (2011). Isolation and characterization of pediocin NV5 producing Pediococcus acidilactici LAB 5 from vacuum-packed fermented meat product. Indian J Microbiol. 51: 22-29.

13. Meesi, P., Bondi, M., Sabia, C., Battini., R. and Mannicardi, G. (2001). Detection and preliminary characterization of a bacteriocin (plantaricin 35d) produced by a Lactibacillus plantarum strain. Int $\mathrm{J}$ Food Microbiol. 64: 193-198.

14. Mohankumar, A., Murugalantha, N. (2011). Characterization and antibacterial activity of Bacteriocin producing Lactobacillus isolated from raw cattle milk sample. Int. J. Biology. 3: 3.

15. Nettles, C.G., Barefoot, S.F. (1993). Biochemical and genetic characteristics of bacteriocin of food associated lactic acid bacteria. J. Food Prot. 56: 338-58.

16. Paul, R.R., Morgan, S. and Hill, C. (2002). Preservation and fermentation: past, present and future. Int J Food Microbiol. 79: 3-16.

17. Ravi, V., Prabhu, M., Subramanyam, D. (2011). Isolation of bacteriocin producing bacteria from mango pulp and its antimicrobial activity. J. Microbiol. Biotech Res. 1(2): 54-63

18. Redondo-Lopez, V., Cook, R.L. and Sobel, J.D. (1990). Emerging role of lactobacilli in the control and maintenance of the vaginal bacterial microflora. Rev Infect Dis. 12: 856-872.

19. Riley, M.A. and Wertz, J.E. (2002). Bacteriocins: Evolution, Ecology and application. Annu Rev Microbiol. 56: $117-137$.

20. Todorov S.D., Dicks, L.M.T. (2004c). Influence of growth conditions on the production of a bacteriocin by Lactococcus lactis subsp. lactis ST34BR, a strain isolated from barley beer. J. Basic. Microbiol., 44: $305-316$.

21. Tynkkynen, S., Singh, K.V. and Varmanen, P. (1998). Vancomycin resistance factor of Lactobacillus rhamnosus GG in relation to enterococcal vancomycin resistance (van) genes. Int J Food Microbiol. 41: 195204.

22. Schillinger, U., Geisen, R. and Holzapfel, W.H. (1996). Potential of antagonistic microorganisms and bacteriocins for the biological preservation of foods. Trends Food Sci Technol. 7: 158-164.

23. Vescovo, M., Oris, C., Scolari, G. and Torriani, S. (1995). Inhibitory effect of selected lactic acid bacteria on microflora associated with ready-to-use vegetables. Lett Appl Microbiol. 21: 121-125. 